in Acute Tubular Failure) are the only contributors to this excellent book who stand outside the distinguished school where Cushny taught.

\section{NEURAL CONTROL OF THE PITUITARY GLAND}

By G. W. Harris, F.R.S., Sc.D., M.D. Pp. ix + 298, with 53 illustrations. London: Edward Arnold Ltd. I 955 . 30s.

The most casual glance through the pages of this book cannot fail to impress. Here is a scholarly work which presents an up-to-date account of the present knowledge about the Pituitary Gland and its anatomical and functional relationship to the Central Nervous System. The arguments brought forward are clearly stated and answered and flow logically on to the next, whilst much of the author's own experimental work is modestly woven into the fabric of newer knowledge.

From all aspects, comparative morphology and physiology, clinical and experimental endocrinology, this is a book of great importance. A random sample shows an account of the transplantation experiments which lead to the recognition of the hypophysical portal system on the one hand, and on the other a delightfully lucid account of observations on the ACTH, Thyrotrophic and Gonadotrophic hormone mechanisms and their clinical implications.

One need say no more than that this book is most strongly recommended.

B.J.H.

\section{THE BLOOD-BRAIN BARRIER}

\section{With special regard to the use of radioactive isotopes}

By Louis Bakay, M.D., F.A.C.S. Pp. xii + I54, with 32 illustrations. Oxford: Blackwell Scientific Publications. 1956. £2.

This is the latest of a line of monographs produced from a well-known publishing house. Perhaps the title of the book will tend to limit its circulation to a relatively small group of scientific readers, but when one examines the subject matter one finds that the author has touched on many matters of importance to clinical neurology.

Essentially this is an account of original work by the author in using radio-isotopic methods for the elucidation of the functional properties of the Blood-Brain Barrier, a physiological structure whose importance has long been clear but whose secrets are only just beginning to be unravelled. Although perhaps clear to those working in this field, it is unfortunate that for those unfamiliar with it the wealth of detail enclosed in these pages tends to obscure the chemico-physiological principles which have emerged as a result of the studies. Nevertheless this is clearly a book of considerable importance and should be read.

\section{POSTURAL DRAINAGE}

By E. Winifred Thacker, M.C.S.P. Pp. viii + 56, with 37 illustrations. London: Lloyd-Luke Ltd. I 956. Price not stated.

The details of physio-therapeutic methods are unknown to most doctors. This small, but excellent, book should be of great value to all who treat patients who might benefit from postural lung drainage. It should enable them to order this treatment more intelligently and supervise its application.

\section{BORDERLANDS OF THE NORMAL AND EARLY PATHOLOGIC IN SKELETAL ROENTGENOLOGY}

By Prof. Dr. Alban Köhler. Revised by Dr. E:

A. ZIMMER, English Translation edited by JAMES

T. CASE, M.D., D.M.R.E. Tenth Edition. Pp. xiv +723 , with 1,300 illustrations. New Yorlo and London: Grune and Stratton, Inc. 1956 $\$ 24,5$.

Prof. Köhler s great book was first translatec into English in 1928, and a further edition was translated in 1935. The present volume is a translation of the tenth German edition, made almost simultaneously with the preparation of the latter. It contains a much larger Bibliography than the parent volume (a tribute to the pains taken by the translator and a reflection, perhaps, of that unhappy period of isolation from which German medicine seems to be emerging only very slowly).

This book must prove indispensable to every department of radiology. It is encyclopaedic in scope, describing and illustrating an enormous number of minor variations and early pathological deviations from the normal. The translation is clear and lucid. There are thousands of references and a full index. The standard of printing (which is German) is very high indeed and the illustrations are very beautifully and clearly reproduced. The translator is to be congratulated on a very high standard of proofreading, so often faulty in a book printed on the Continent. 